\title{
BAHASA NARATIF DALAM KOMUNIKASI ARSITEKTUR
}

\author{
Ari Widyati Purwantiasning \\ Jurusan Arsitektur Universitas Muhammadiyah Jakarta \\ arwityas@yahoo.com
}

\begin{abstract}
Diterima: 07-05-2020 Direview: 07-09-2020 Direvisi : 04-10-2020 Disetujui: 05-10-2020
\end{abstract}
\begin{abstract}
ABSTRAK. Tulisan ini merupakan sebuah kajian tentang bagaimana mengungkapkan sebuah karya arsitektural, gagasan maupun ide dalam sebuah Bahasa naratif yaitu tulisan. Beberapa teori tentang Bahasa naratif tersebut disajikan oleh beberapa ahlinya sebagai sebuah dasar dan referensi dalam mengungkapkan tiga buah studi kasus yang akan ditinjau. Tinjauan yang dilakukan terhadap tiga studi kasus tersebut menggunakan metode kualitatif deskriptif naratif, dimana Saya mencoba untuk mengungkapkan kekuatan penulis dalam gaya penulisannya terutama dalam menggiring opini pembaca baik negatif maupun positif bahkan imaginatif. Tulisan ini akan memberikan wacara bagi para calon arsitek yaitu mahasiswa arsitektur atau para civitas akademika lainnya sehingga dapat lebih memahami bagaimana seharusnya sebuah karya arsitektural baik bangunan maupun ruang arsitektural harus diungkapkan untuk mempersuasi pembacanya.
\end{abstract}

Kata Kunci: naratif, linguistik, komunikasi, arsitektur

ABSTRACT. This paper is a research about how to express and describe an architectural masterpiece, idea, and thought into a written narrative language. Some theories about narrative language and linguistic language have been discussed in this article and have been used as a primary reference in discussing three case studies. I have reviewed three case studies using a qualitative method with a narrative descriptive approach. I have tried to reveal the author's power with their character and style of their written language, mainly how to persuade the reader either negatively, positively, and imaginatively. This research will give architecture students a new discourse to understand how an architectural masterpiece should be described in a written narrative language to persuade the readers.

Keywords: narrative, linguistic, communication, architecture

\section{PENDAHULUAN}

Purwantiasning (2004) memaparkan bahwa tanpa komunikasi, sebuah pesan atau berita tidak dapat disampaikan dengan mudah dan sesuai dengan maknanya. Begitu juga dengan ide atau konsep yang biasanya hanya terpikirkan dalam sebuah pikiran juga tidak akan bermakna jika tidak dituangkan dalam sebuah komunikasi. Dalam komunikasi diperlukan sebuah bahasa sebagai pengantar dalam menerjemahkan buah pikiran seseorang. Dalam hal komunikasi ini, bahasa memiliki kontribusi besar sebagai media untuk mengekspresikan sesuatu. Salah satu bentuk komunikasi adalah dengan memaparkannya dalam sebuah tulisan. Tuan (1991) mengklasifikasikan pendekatan penulisan menjadi 3 yaitu pendekatan linguistik alami, sosial linguistik dan yang terakhir adalah naratif deskriptif. Ketiga pendekatan ini memiliki karakternya masing-masing.

Tulisan ini akan membahas tentang bagaimana sebuah bahasa naratif penting dalam komunikasi sehari-hari terutama dalam menjelaskan dan mendeskripsikan visualisasi sebuah karya arsitektur maupun berbagai hal yang berkaitan dengan arsitektur. Tidak sedikit arsitek atau bahkan calon arsitek yaitu dalam hal ini mahasiswa arsitektur yang tidak dapat mengungkapkan ide maupun gagasannya dari bentuk visual ke dalam komunikasi naratif yaitu dengan kata-kata baik tertulis maupun secara lisan. Berbagai bentuk atau cara mengungkapkan bahasa naratif tersebut akan dijelaskan dengan memberikan tiga buah contoh paparan naratif sebuah karya arsitektural baik berupa bangunan maupun berupa ruang terbuka.

\section{PENDEKATAN LINGUISTIK}

Seperti yang disampaikan Tuan (1991), bahwa dalam sebuah penulisan ada tiga pendekatan yaitu pendekatan linguistik alami, sosial linguistik dan naratif deskriptif. Pada pendekatan linguistik, didasari oleh tata bahasa yang memberi gambaran tentang aspek suatu obyek atau tempat yang ditegaskan dalam bentuk majemuk maupun tunggal, jauh atau dekat dan segala hal yang berhubungan dengan aktifitas sederhana. Pendekatan ini akan membawa sebuah fakta kepada persepsi seseorang terhadap fakta 
tersebut. Pendekatan yang kedua yaitu pendekatan sosial linguistik adalah pendekatan yang berkaitan dengan yang ada pada kehidupan masyarakat kita. Konteks pada pendekatan ini adalah pada marginalitas dimana pemahaman sebuah komunikasi hanya terjadi pada kelompok komunitas tertentu yang belum tentu atau bahkan tidak mungkin untuk dimengerti oleh kelompok sosial atau komunitas lainnya. Pendekatan yang terakhir adalah naratif deskriptif yang seringkali tidak dapat dihindari digunakan dalam keseharian kita. Segala komunikasi lebih banyak menggunakan pendekatan ini dimana di dalamnya terdapat unsur dalam mendeskripsikan sesuatu dengan alur cerita atau peristiwa dari waktu ke waktu sehingga menjadi sebuah narasi (Tuan, 1991).

Sebagai contoh dalam sebuah ulasan karya arsitektur, sebuah gambar arsitektur yaitu denah, tampak dan potongan menjadi tidak penting ketika yang terlihat hanya gambar tanpa ada narasinya. Banyak media yang menggunakan pendekatan naratif deskriptif ini dalam mengulas sebuah karya arsitektural dengan menguraikan detail-detail sebuah desain dan merangkainya menjadi sebuah alur cerita. Sebuah tulisan dari hasil penelitian juga akan menggunakan pendekatan ini, ketika cara penulisannya adalah dengan menguraikan sesuatu fakta yang kemudian dianalisis sehingga menghasilkan sebuah fakta baru, hal ini tentunya merupakan sebuah alur cerita yang menjadi sebuah narasi (lihat Gambar 1). Contoh lain adalah sebuah novel yang dituangkan dengan gaya bahasa dan narasi yang dramatis juga dapat menghadirkan ruang dalam pikiran pembacanya. Gambaran yang disajikan di dalam cerita novel akan membawa imaginasi pembacanya ke dalam ruang yang ada di dalam cerita tersebut. Pendekatan naratif deskriptif ini membawa pembaca untuk memaknai setiap rangkaian kata dan kalimat di dalam sebuah tulisan menjadi sesuatu yang terkesan nyata.

Tuan (1991) juga mengungkapkan bahwa sebuah komunikasi dapat menjembatani antara lingkungan dan perilaku orang yang melakukan komunikasi tersebut. Tuan juga memaparkan bahwa kekuatan bahasa dapat dieksplor dengan beragam skala menggunakan cara dan pendekatan yang berbeda, setidaknya Tuan menguraikan ada 3 cara dan pendekatan yaitu melalui budaya, sosial politik dan linguistik-literatur murni.

Lain halnya Tuan yang berbicara masalah pendekatan dalam komunikasi verbal, Becker
(1986) mengemukakan masalah gaya bahasa yang dapat menunjukkan citra penulis bahkan authorship dari penulis. Pada awal tulisan Howard \& Becker, diuraikan sebuah contoh kasus yang disajikan dalam ulasan tulisan seseorang. Dari uraian tersebut dapat diambil beberapa inti, bahwa dalam sebuah tulisan harus dihindari beberapa hal:

- jangan terlalu banyak kata-kata

- efisiensi kata dengan memilih istilah yang lebih singkat dan dimengerti

- hindari kata-kata yang tidak bermakna

- hindari pengulangan frase yang berkepanjangan

- membuang kata-kata yang tidak efektif

- buat kalimat-kalimat yang lebih pendek dan jelas sehingga akan lebih berkelas

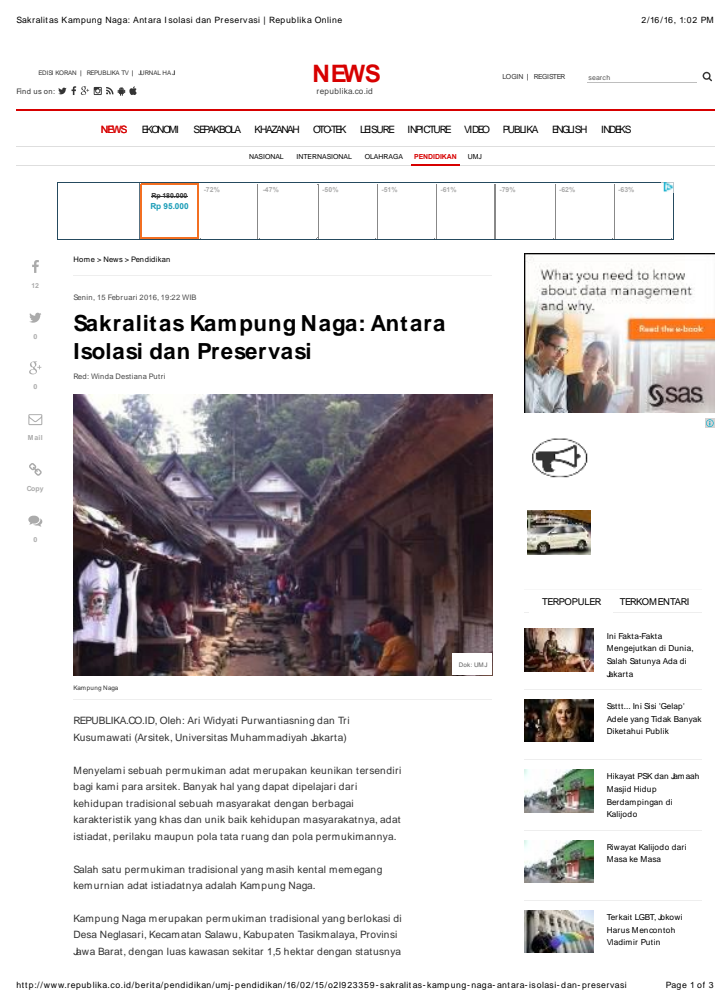

Gambar 1. Sebuah contoh bagaimana kekuatan tulisan dapat menggiring pembaca dalam mengimajinasikan sebuah ruang arsitektural di Kampung Naga

Sumber: Dokumentasi penulis, 2016

Dari uraian Becker (1986) di atas muncul kata "classy" atau "berkelas", apa yang dimaksud dengan kata tersebut adalah menunjukkan tentang berkelasnya sebuah tulisan karena penggunaan gaya bahasa tertentu. Sebuah tulisan dapat dikenali berkelas atau tidaknya dengan membaca konten dari tulisan tersebut. Semakin bertele-tele tulisan atau semakin tidak tidak pentingnya tulisan sehingga justru 
menimbulkan pertanyaan apa sebenarnya inti tulisan tersebut, akan menjadikan citra si penulis jelek di mata pembaca. Sebaliknya sebuah tulisan yang berbobot akan membuat pembaca berpikir bahwa penulis adalah seseorang yang memiliki karakter kuat atau justru bahkan muncul citra bahwa penulis adalah orang yang cerdas sehingga bisa menghasilkan tulisan seperti itu. Citra yang muncul dari persepsi pembaca inilah yang disebut Becker dengan istilah "persona". Becker (1986) juga menyebutkan bahwa "berkelas" dapat disejajarkan dengan "berintelektual" atau "cerdas". Sehingga tulisan yang berkelas dapat disebut sebagai tulisan yang berintelektual.

\section{Pengalaman Ruang Arsitektural Kota Museum Krefeld}

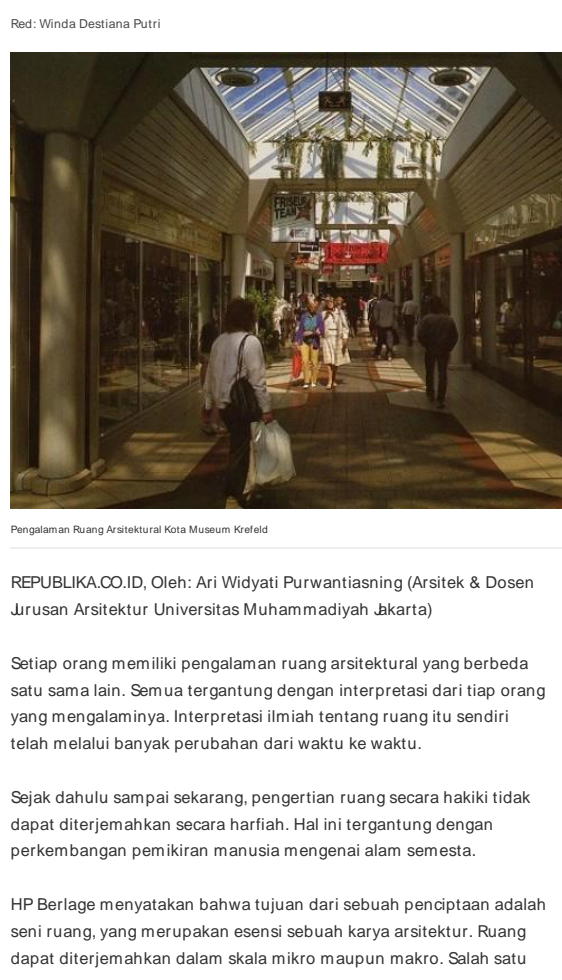

Gambar 2. Sebuah contoh bagaimana narasi tulisan dalam mendeskripsikan ruang arsitektural sebuah kota di Eropa yaitu Kota Kreffeld yang dikenal sebagai Kota Museum

Sumber: Dokumentasi penulis, 2016

Sebagai contoh dalam pengalaman pribadi penulis adalah ketika membaca puisi maupun prosa karya Kahlil Gibran, secara pribadi persepsi yang saya tangkap terhadap orang ini adalah: "cerdas banget ini orang". Lain lagi halnya ketika membaca novel-novel karya Umar Khayam dengan karakter beliau yang "down to earth" dan "senang bergurau", semuanya tertuang dalam karya-karya beliau, dengan membaca karyanya, secara pribadi saya seperti mengenal beliau lebih dekat. Karya-karya seperti "Mangan ora Mangan Kumpul' memberikan makna tersendiri di dalam pribadi saya sebagai orang Jawa yang seolah-olah mendapatkan pengetahuan baru dengan banyaknya filsafat hidup yang disampaikan beliau dalam tulisan-tulisannya. Hal inilah yang disebut "persona" oleh Becker. Becker (1986) juga menyebutkan istilah "authority" yang kemudian dikaitkan dengan "authorship". Istilah ini berkaitan dengan kemampuan penulis dalam menuangkan ideide baru sehingga dapat menggantikan ide-ide lama menjadi memiliki nilai baru. Sebagai contoh adalah karya JK Rowling, serial novel Harry Potter. JK Rowling memperlihatkan authorship-nya yang begitu kuat dengan menghadirkan ide-ide baru dalam menyajikan sebuah karya cerita fiksi yang berbeda. Kemampuan berimaginasi JK Rowling mengajak pembaca juga menikmati imaginasinya dalam ruang-ruang waktu yang diciptakannya. Jenis novel fiksi yang berbeda ini tentunya menjadi sesuatu yang fenomenal dalam dunia cerita fiksi yang pada akhirnya membuat pembaca selalu dibuat penasaran untuk menanti kelanjutan cerita-cerita berikutnya.

Literatur ketiga yang dikaji di sini adalah tulisan Barnes \& Duncan (1992) yang memaparkan tentang tiga konsep utama atau tiga kunci utama dalam menulis atau merepresentasikan sesuatu. Ketiganya adalah teks, diskursus dan metafora. Kaitan ketiganya adalah bahwa sebuah tulisan/ bacaan (text) harus dikomunikasikan/ disampaikan dengan sebuah wacana yang melibatkan satu bacaan dengan bacaan lainnya (discourse) sehingga bila terjadi pengibaratan sesuatu yang abstrak dapat menjadi nyata, hal ini dapat dikatakan bila kita mengatakan atau mengemukakan sesuatu yang kita pikirkan dengan perumpamaan seperti sesuatu yang kita kenal baik (metafora) (lihat Gambar 2).

Barnes \& Duncan (1992) juga menyampaikan bahwa sebuah tulisan harus dapat merefleksikan sebuah fakta sehingga dapat melibatkan interpretasi penulis, dimana sebuah tulisan harus didasari oleh tulisan lainnya. Dari pernyataan ini maka muncullah istilah "intertextuality" yang dapat dimaknai sebagai sebuah proses dimana pemaknaan dihasilkan dari satu tulisan ke tulisan lain.

\section{METODE}

Tulisan ini merupakan sebuah kajian mengenai Bahasa naratif yang 
mendeskripsikan sebuah karya visual dalam sebuah tulisan. Tulisan dihasilkan dengan menggunakan metode kualitatif deskriptif naratif, dengan mengkaji beberapa teori yang disajikan oleh beberapa ahli dan kemudian dikaitkan dengan mengkaji tiga buah contoh penulisan Bahasa naratif dari karya arsitektural baik berupa bangunan maupun berupa ruang arsitektural. Dalam proses analisisnya, dilakukan komparasi dari tiga buah studi kasus yang dipilih, Ketiga contoh yang disajikan dibandingkan satu sama lainnya untuk melihat perbedaan dan persamaan dari ketiganya. Tulisan ini tentunya akan menjadi wacana yang penting mengingat masih banyaknya arsitek maupun calon arsitek yaitu mahasiswa arsitektur yang masih lemah dalam mengkomunikasikan karya, ide dan gagasannya melalui bahasa naratif. Sebagai hasil akhir dari paparan ketiga studi kasus, maka dapat ditarik benang merahnya, bahwa dalam komunikasi Bahasa naratif terutama dalam bidang arsitektur, sangatlah penting seni persuasive atau dalam hal ini bagaimana menggiring opini dari pembaca, sehingga pembaca dapat tertarik dan terpengaruh oleh isi tulisan dari penulis.

\section{HASIL PENELITIAN DAN PEMBAHASAN}

Dari ketiga teori di atas yaitu teori-teori yang disampaikan oleh Tuan (1991), Becker (1986) serta Barnes \& Duncan (1992), maka tiga contoh tulisan dapat dianalisis sebagai berikut:

\section{Sydney's Opera House: Peter Hall}

Hall (1980) dalam tulisannya dalam bukunya Great Planning Disasters (lihat Gambar 3), memperlihatkan kemampuannya dalam menyajikan data-data sehingga memperkuat fakta-fakta yang disajikan olehnya. Hall juga mencoba untuk mengajak pembaca agar dapat melihat fakta tentang mahakarya arsitektur Sydney Opera House ini dari sisi yang berbeda, yaitu dari sisi negatifnya. Khalayak sudah terbiasa terbuai dengan kemegahan mahakarya arsitektur ini, dan apakah dengan membaca tulisan Hall, masyarakat akan menjadi terpengaruh? Tidak dapat dipungkiri tulisan miring tentang Sydney Opera House karya Hall ini sedikit banyak akan merubah opini masyarakat tentang Sydney Opera House.

Paparan Hall di awal tulisan memperlihatkan pendekatan naratif deskriptif seperti yang Tuan (1991) sampaikan sebelumnya. Uraian dan alur cerita tentang apa itu Sydney Opera House dan bagaimana bangunan ini merupakan mahakarya arsitektur disampaikan pada paragraf pertama yang kemudian pada paragraf kedua mulai berubah menjadi awal dari persepsi negatif Hall mengenai bangunan ini dengan menyebutnya sebagai "Planning Disaster."

Pada bagian berikutnya Hall mengemukakan berbagai data dan fakta secara runut dan beraturan dari dimulainya proses kompetisi, kontrak sampai dengan konsep disain dimulai dan diselesaikannya bangunan tersebut. Dan tulisan diakhirinya dengan berbagai analisis melalui data-data yang dipaparkan sehingga muncul kesimpulan bagaimana proyek bangunan ini merupakan bencana. Hall (1980) mencoba untuk menggiring opini publik melalui tulisannya secara negatif, pada akhir tulisan tentunya pembaca akan menyimpulkan sendiri apakah memang proyek bangunan Sydney Opera House ini dapat dikatakan sebagai bencana atau tidak? Namun setidaknya pemakaian kata "bencana" oleh Hall memberikan dampak besar dalam imaginasi pembacanya.

Di dalam pikiran pembaca akan banyak berkecamuk berbagai pertanyaan, persepsi, opini baik negatif maupun positif dalam menanggapi tulisan Hall tersebut. Setidaknya publik yang tadinya tidak memiliki opini negatif terhadap Sydney' Opera House, setelah membaca tulisan Hall akan muncul pemikiran baru bahwa di balik proses pembangunan megahnya bangunan ini terdapat hal-hal negatif. Kemampuan Hall dalam menuangkan tulisan dengan opini negatif inilah yang dapat dikatakan bahwa Hall memiliki "persona" kuat sebagai seseorang yang memiliki karakter "negatif" dalam membuat tulisan-tulisan kritik arsitektur. Ide-ide baru Hall yang mencoba melihat sesuatu dari sisi yang berbeda yang menggantikan opini publik tentang sesuatu yang positif menjadi sesuatu yang negatif dapat dikatakan sebagai "authorship" seorang Hall. 


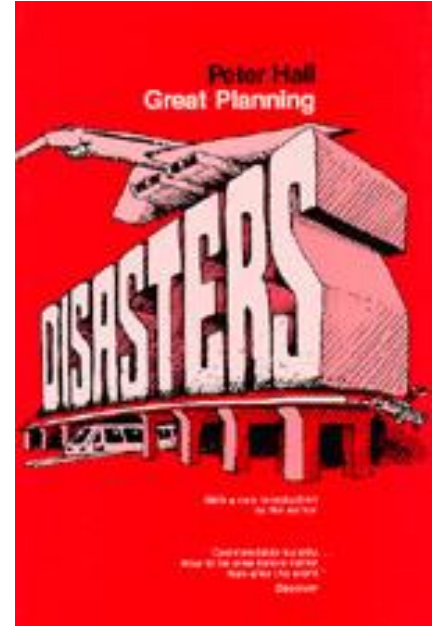

Gambar 3. Buku karya Peter Hall yang membahas tentang beberapa mahakarya arsitektur di dunia yang dianggapnya sebagai bencana Sumber: Dokumentasi penulis, 2016

\section{Tienanmen Square: Mckenzie Wark}

Berbeda dengan Hall (1980), Wark (1994) dalam tulisannya (lihat Gambar 4) justru tidak menggiring opini pembaca, namun memberikan ruang bagi pembaca untuk mempersepsikan sendiri isi tulisan yang ditangkapnya dan memaknainya berdasarkan pemikiran pembaca masing-masing.

Pada awal paragraf, Wark (1994) menggunakan pendekatan linguistik dengan menekankan kalimat bahwa tulisan ini dalam "present tense", kemudian Ward juga menggunakan pendekatan naratif deskriptif untuk mengajak pembaca larut dalam situasi dan suasana saat kejadian/ peristiwa tersebut berlangsung di Beijing Cina di tahun 1989.

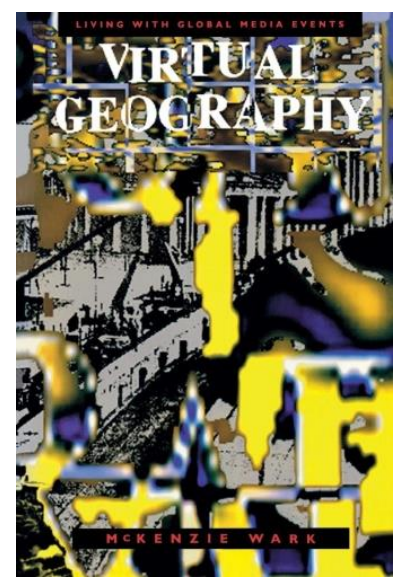

Gambar 4. Buku karya Mckenzie Wark yang membahas tentang bagaimana persepsi pembaca digiring berdasarkan narasi deskripsi yang kuat yang disajikannya

Sumber: Dokumentasi penulis, 2016
Dalam alur ceritanya, Wark (1994) lebih banyak menggunakan persepsinya dalam mengemukakan kejadian/ peristiwa tersebut, sehingga lebih terkesan menjadi sebuah spekulasi daripada sebuah fakta yang terjadi di lapangan. Sebagai contoh saat Ward mengungkapkan apa isi dari tas belanja yang dibawa oleh "Tank Man" yang mencoba untuk menghentikan aksi tank di depannya. Apakah sebegitu pentingnyakah tas belanja tersebut, sehingga Ward justru mengajak pembaca untuk membiaskan fokus pembaca dari kondisi "Tank Man" yang mungkin menimbulkan suasana mencekam bagi pembacanya, menjadi kondisi dimana pembaca ikut larut memikirkan apa isi tas tersebut. Apa isi dalam tas belanja tersebut tentunya menjadi pertanyaan bagi pembaca, yang dideskripsikan Ward bahwa tas tersebut terlihat berat di matanya, hal ini berupa persepsi dan spekulasi Ward terhadap gambaran di matanya. Hal ini mengajak pembaca untuk memberikan persepsi dan spekulasi juga atas tulisan Ward. Mungkinkan itu berisi bom yang akan menjadi bom bunuh diri? Ataulah memang isinya benar-benar hanya hal yang tidak berarti dan tidak berhubungan dengan peristiwa pemberhentian tank tersebut? Hal ini tergantung dari ruang imaginasi para pembaca tulisan Ward ini.

Dengan tulisannya, Wark (1994) menunjukkan "persona" nya sebagai seorang penulis. Dengan fakta yang ada Ward berhasil membumbui tulisannya dengan kalimat-kalimat yang dapat mengajak imaginasi pembacanya untuk menciptakan persepsi masing-masing.

\section{Monument and Myth: David Harvey}

Dalam tulisannya, Harvey (1989) mencoba untuk memaparkan sebuah sejarah tentang bergejolaknya kondisi politik dan agama di masa itu di Paris. Tulisan Harvey merupakan diskripsi sejarah yang membahas tentang berdirinya monumen Basilica sebagai jantung kota Paris yang secara mitos dianggap suci. Pada awal paragraf, Harvey menceritakan kondisi eksisting dari lokasi monumen, sehingga pembaca dapat membayangkan posisi "place" dari monumen tersebut (lihat Gambar 5). Hal ini penting karena dengan adanya gambaran sebuah tempat maka pembaca dapat lebih mudah untuk mengerti isi tulisan selanjutnya. Gaya bahasa metafora juga diperlihatkan dalam beberapa kalimat seperti pada halaman 366 pada paragraph 6 kalimat pertama yang berbunyi "from the other end of the telescope, Paris was generally seen as a center of power, domination, opportunity. It was both envied and hated." 
Kalimat-kalimat yang disajikan oleh Harvey (1989) mengandung makna sejarah di dalamnya, pembaca diajak untuk menyelami sejarah masa lalu dengan banyaknya faktafakta yang diberikannya. Walaupun cukup sulit untuk memahami isi tulisan ini, karena banyaknya istilah-istilah Perancis, namun alur cerita yang diberikan oleh Harvey setidaknya cukup memberikan pemaknaan tersendiri bagi pembacanya. Beberapa pendekatan dalam tulisan ini digunakan oleh Harvey dari mulai pendekatan naratif deskriptif yang menceritakan deskripsi sejarah masa lampau dengan alur peristiwa dan sejarah yang jelas sampai dengan pendekatan sosial politik linguistik, dimana di dalamnya terdapat bahasan tentang isu-isu politik dan agama yang merupakan bagian dari sejarah Paris pada masa itu.

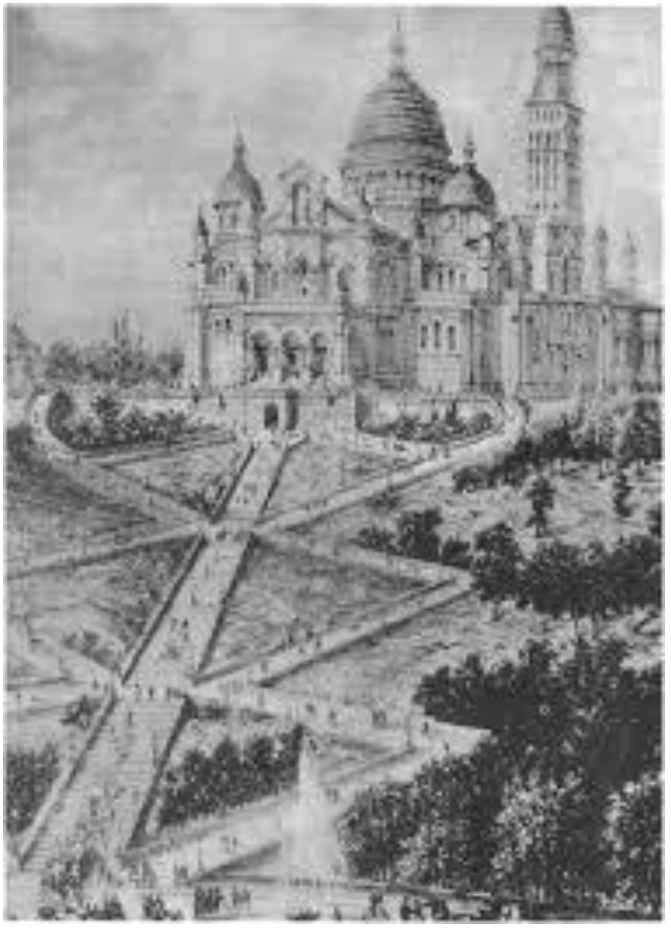

Gambar 5. Gambar visual di atas menjadi lebih hidup dengan kekuatan narasi yang disajikan oleh Harvey dalam tulisannya tentang Monumen Basilica Sumber: Harvey, 1989

Dengan gaya bahasanya, Harvey (1989) mencoba memperlihatkan bagaimana karakternya sebagai seorang penulis. Sekilas membaca tulisannya, pembaca memiliki persepsi bahwa Harvey adalah seorang sejarawan karena kemampuannya dalam menuangkan tulisan dengan runut peristiwa sejarah masa lalu di Paris.

\section{KESIMPULAN}

Paparan di dalam tulisan ini setidaknya telah memberikan gambaran bagaimana seharusnya seseorang mengungkapkan pikiran, ide dan gagasannya melalui tulisan dengan pendekatan deskriptif naratif. Pendekatan deskriptif naratif dianggap sebagai pendekatan paling mudah dalam mengungkapkan sesuatu, karena pendekatan ini difokuskan dalam mendeskripsikan atau menceritakan fakta-fakta yang ada sesuai yang dilihat melalui narasi. Kekuatan seseorang dalam mengungkapkan sesuatu sehingga memberikannya karakter tersendiri dalam sebuah tulisan ini yang disebut sebagai persona seperti yang diungkapkan dalam teori di atas. Komuniasi dalam Bahasa naratif diperlukan suatu strategi dan gaya Bahasa tertentu yang dapat mempengaruhi opini pembaca, hal ini disebut sebagai seni persuasif.

Dari ketiga tulisan dalam studi kasus di atas diperoleh bagaimana penulis mencoba untuk mempengaruhi dan menggiring opini pembaca saat membaca isi dari tulisan. Dengan adanya penggiringan opini inilah, maka dimaksudkan agar pembaca setuju dengan isi tulisan tersebut, dalam hal ini tentunya penulis memiliki kekuatan sehingga pembaca terpengaruh oleh isi tulisannya. Hal ini tidak jauh berbeda dengan para arsitek yang mencoba menggiring opini pembaca ataupun para klien dalam membaca isi tulisanulasan mengenai sebuah karya arsitektur terutama karya arsitektur si penulis. Pembaca dalam hal ini calon klien atau bahkan klien tentunya akan terpengaruh dengan isi tulisan si arsitek sebagai penulis sehingga dapat terpengaruh dan tertarik untuk melihat karya-karya arsitekturnya atau bahkan ingin mewujudkan impiannya dalam membangun sebuah karya arsitektur melalui si arsitek. Diharapkan dengan adanya tulisan ini, maka para calon arsitek terutama mahasiswa arsitektur ataupun civitas akademika lainnya dapat bertambah wawasannya, sehingga tidak ada lagi keraguan dalam mengungkapkan sebuah karya arsitektur, ide maupun gagasan melalui bahasa linguistik baik tulisan maupun lisan.

\section{REFERENSI}

Barnes, T., \& Duncan, J. (1992). Introduction: Writing Worlds. In Writing Worlds (pp. 117). Routledge.

Becker, H. S. (1986). Persona and Authority. In Writing for Social Science (pp. 26-42). University of Chicago Press. 
Hall, P. (1980). Sydney Opera House. In Great Planning Disaster (pp. 138-151). UC Press.

Harvey, D. (1989). Monument and Myth. In Urban Experience (pp. 200-228). john Hopskin University Press.

Purwantiasning, A. W. (2004). Komunikasi Dalam Arsitektur (Bahri, S., ed.). Jakarta: Bias Arkade.

Tuan, Y. F. (1991). Language and Making of Place. Annal of the American Association of Geographers, 81(4), 684-696.

Wark, M. (1994). Tienanmen Square. In Virtual Geography (pp. 96-163). Indiana University Press. 
